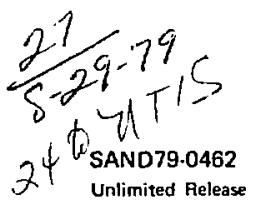

\title{
Measurement of Water Lost From Heated Geologic Salt
}


SAND79-0462

Unlimited Release

Printed July 1979

MEASUREMENT OF WATER LOST FROM HEATED GEOLOGIC SALT

Jacque J. Hohl felder

Experiments Planning Division 1112

Sandia Laboratories

Albuquerque, NM 87185

\begin{abstract}
This report describes three methods used to measure the rate at which water is 1 nst from heated genlogic salt. The three methods were emplnyed in each of a series of "pronf" tests which were performed to evaluate instrumentation designed to measure the waterloas rate. We frund that the water lost from heated, 1-kg aalt specimens which were measured according to these three tsethods was consistent to within an average 9 percent.
\end{abstract}




\section{ACKNOWLEDGMENTS}

Ramon Villegas performed much of the instrumentation, procurement, assembly, and checkout for this experiment. I greatly appreciate the help of Art Arthur and Dick Baff in the heater design and fabrication. 


\section{CONTENTS}

Page

Introduction 7

Procedure B

Firat Water-Los Meagurement Hetho' 10

Second Water-Lose Measurement Method 10

Third Water-Lose Measurement Method 11

Test Resulta 13

Sumary 16

Refereaces 16

APPENDLX A - Man Loas Upon Heating of Geologic Salt 


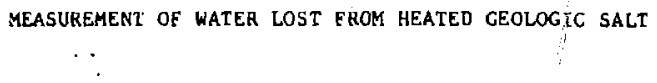

Introduction

Sandia Laboratories is researching the basic properties of geologic salt to aid in the design of the Waste Isolation Pilot Plant (WIPP) facility. The water content of geologic salt is essential in understanding the processes by which water may be transported in the region surcounding a heat-producing waste cannister placed in geologic 6alt. The experiment wich is described here was designed to measure water lost from samples of geologic salt.

This report describes three methods used to measure the rate at which water is lost or evolved from heated geologic salt. The three methods were employed in each of three "proof" tests which were performed to evaluate instrumentation designed to measure the water-loss rate. The three methods used to determine the amount of water loss are:

1. Heasurement of the specimen's mass loss upon being heated.

2. Measurement of the mass increase of a desiccant material that has been placed in the gas-flow stream wich had passed over the heated salt.

3. Integration of the time rate of water introdiced into the gas-flow atceam which had been passed over the heated salt. Water intraduced into the gas-flow stream was measured using comercially available dew point hygrometers, absolute pressure gauges, and mass flow rate gauges. 
Procedure

Each salt specinen, which weighed approximately $1 \mathrm{~kg}$, was a 5.0 -cmhigh cylinder with a diameter of $10.8 \mathrm{~cm}$. The cylinders were machined from separate I-m-long cubic salt blocks supplied by the Mississippi Chearical Company from their mine located about $29 \mathrm{~km}$ east of Carlsbad, New Mexico. The salt blocks were removed from ore zone 7, approximately $210 \mathrm{~m}$ bilow the surtace in the McNutt Potash Zone of the Salado Formation. The najur mineralogical constituents of the rock salt are approximately as Hllows: 88 percent halite, 5 percent kainite, 4 percent polyhalite, and 3 percent sylvite. Since, between the time they were mined and prior to tsing heated, the specimens were exposed for up to one year to a labueatory air environment, their water content and permeability may Jif $1: \mathbf{r}$ frum that of in situ salt.

Each specimen was weighed and placed into a gas-tight, stainless steel enclosure with a diameter of $15 \mathrm{~cm}$ and a height of $18 \mathrm{~cm}$. The simple was heated using electrical heater tape wrapped around the circumfecente of the enclosure. Thermal insulation (fiberglass mat, vermi¿ulite, and transite) was placed over the heater rape and surrounded all surtaces of the enclosure. A section view of the sample-heating enclosure is shom in figure 1 . The temperature of the heated salt specimen was meisured using a thermocouple in contact with the specimen's top surface. fach specimen was heated sequentially at the three input power levels $(0$, 07, and $116 \mathrm{~W})$ of the heater tape. For each heater power level, both the time required for the specimen to rench its maximus temperature and the specinen's maximum temperature were affected by the thermal insulation and by the ambient temperature $\left(20^{\circ}\right.$ to $\left.30^{\circ} \mathrm{C}\right)$. The duration of each run was abant 8i) hours. The water that evolved from the heated salt was picked up by passing a pure (99.998 percent by weight) dry nitrogen gas stream continuously througl the enclosure containing the salt. The gas stream's Llow rute, about 400 standard cubic centimeters per minute (SCCM), and the salt spesimen's maximum water-loss rate precluded aturation of the flow gats wilh respect to water. The gas etream*s water vapor content, mass flow rate, temperature, and absolute pressure were measured using the 
instruments shown schematically in Figure 2. The experimental, parameters for each specimen are shown in Table 1.

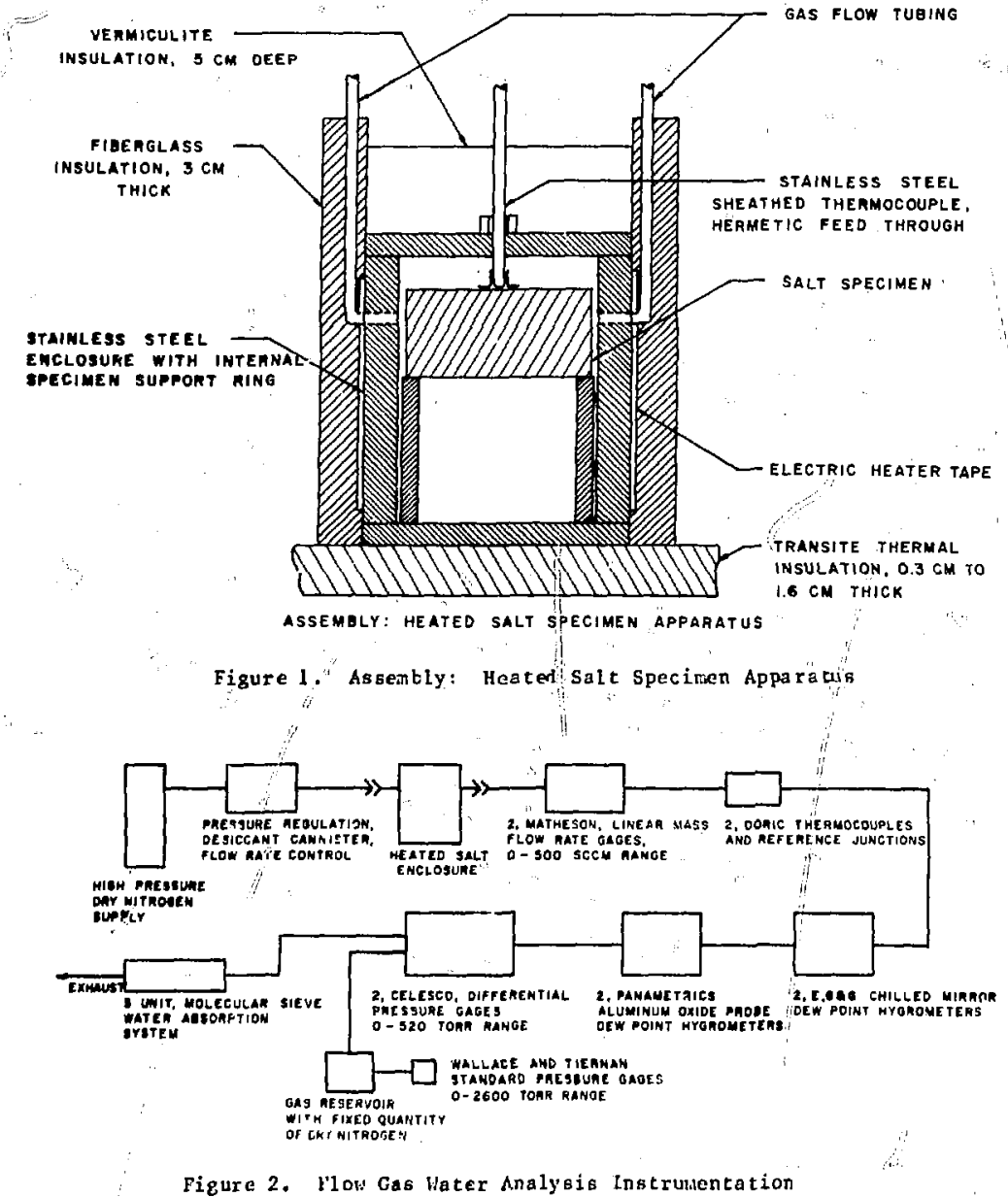


TABLE 1
(i) Experimental Parameters for Heated Salt" Spécimens

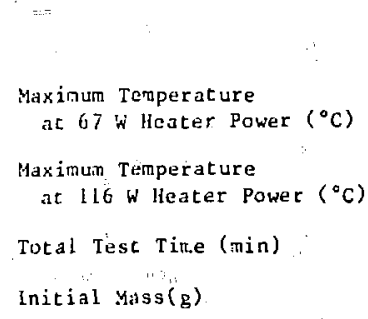

In the first method used to measure the specimen's water content, we measured the mass of the salt specinen before and after heating, and the speciman's mass 'loss'upon heating was assumed to be due to the loss of water. "This mass Ioss is really an upper bound to the water lost during heating since other volatiles such as carbon dioxide may be lost in the lleaced salt in addition to water. No estimate of the error in the specimen's mass loss due to such processes is included. "The absolute accuracy of the measurement of the mass of each specimen was estimated as $+0.02 \mathrm{~g}$. Eie specinen aid not lose more than $0.03 \mathrm{~g}$ in the form of salt fines or Ilakes when it was remoived from the enclosure for weighing. After being soo:s to room cemperature, the specimens were weighed within ten minutes sf thir renoval from the enclosure; some weight gain due to the absorption of water from the air may have occurred although no eatimate of the mass etror caused by this effect is included. The estinated total error in each specimen's mass loss measurement is $+0.06 \mathrm{~g}-0.03 \mathrm{~g}$.

\section{Second Water-Loss Measurement Method}

In the second-method used to measure the specimen's water content, we thasuced tha mass increase of three nolecular sieve desiccant cartridges which were placed in the gas-flow stream downstream from the salt 


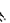

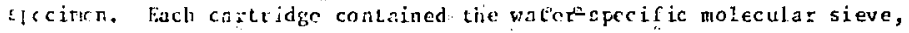
l.inde-4A (Hatheson model 452), and each cartridge's water absorption cepacity was $6 \mathrm{~g}$. Fach cartridge was weighed prior to the placement of the salt specimen into the heating enclosure; they were then weighed again fullowing the heating of the salt specinen and the subsequent cooling of the heating enclosure to roan temperature. The total of the mass increases of the desiccant carfyridges vas a measure of the water lost by the salt'specimen. "An error in this quantity arises because the water vapor in the gas-flow stream is incompletely absorbed by a single desiccant cartridge. We minimized this error by flowing nitrogen through the cartridges in series, and then by adding to their descending sequence of mase gain an additional mass gain which vould have occurred if an infinite series arriy of desiccant cartriages, had been used. Water desorption by the enclosure and subgequent absorption by the cartridges." moy be a source of error. Finally, the dry nitrogen flow gas is net necessarily in equilibriur with the enclosure at the beginning of the", measurcment; this may be a source of systamatic error. An estinated error of $0.05 \mathrm{~g}$ was assigned to each water absorption measur etant.

\section{Third Hater-Losg Measurement Method}

In the tirird mettod used tc meas ure the specinen's water content, we calculated the rate at which weter was incroduced into the nitrogen gasflow stream from the measured parameters of the $f 1 c$ gas; th is yas integrated cver time to give the total amount of went lost by the salt. The rate at which water was introduced into the gas-l low trear was determined by measuring the gas strcam's absolute humidity, abolute pressurc, absolute temperature, and mass flow rate. The dew point of the flar gus was measured using four dew point "hygraneters: two chilled rirror-type hygromcters and two activated al uninum oxide sensor-type hygratetcrs. All equilibrium dew point of 1 ess than $-80^{\circ} \mathrm{C}$ diaracterized the dry nitrogen source gas. The increase in the dew point of the flow gas was due to its ahoorption of water from the oalt sample as well as from the gas-flow hardware. By runing a "Lleak," we eftimated the amounc of water desorbed from the system. This prosens opens the cliclosure to" air, reseals the enclosure with no al tample insids, and then heats the enclooure to drive of the absorbed woter. 
The gas-riow systom absolute pressure was measured using celesco diffcrential pressure transducers which vere calibrated against certified rallece and Tiernan pourcion tube pressure gauges. Nitrogen mass flov rates vere resured ting te theson linear mass flow transducers which had bccr calibrated for air, but which were corrected to indicate nitrogen rase flow. The abscilut temperature of the gas-flow stream was measured usim: copper-conetantan themocouples and Doric-brand signal conditioning inc the rtiocomple readouts.

Ti:e rate at ulich water is intraduced into the gas-ilow stream is givn by

$$
W_{f}=\frac{P\left(I_{2} \mathrm{O}\right)}{P_{T}} \cdot F R \cdot 7.64 \times 10^{-4},
$$

whercllf is the flow rate of taler from the salt into the gas strem (a. $\left.\mathrm{rin}^{-1}\right), P\left(\mathrm{H}_{2} \mathrm{C}\right)$ is the net partial pressure of water in the gas-flow stress due jo-the salt (Jorr), i.e., the difference between the measured watcr partial pressure and the partial. pressure of water due to background sources. $P_{T}$ is the atsolute pressure of the gas-flow strean (Torr). FR is the ritrogen gas-1low rate (SCCM). The partial pressure of the water ve por in che gas strcam is calculated from the neasured dew point

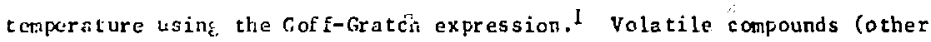
then watcr) which condence or the chilled mirtors of the dew-point gauges were a fource ci bystematic crror in the geasurement of the gas flow's dew poirt. We rceluced the effects of this phenamenon by using an in-line activated clascoal Eilter, cleaning and baking the gas-flow hardware, and frequently cleanirg the deu poirt gauge mirrors. A systematic error is introduced in the detemination of the water evolved from the heated salt itue to an estirated erzor in the measured dew point: $+2{ }^{\circ} \mathrm{C} \pm 1^{\circ} \mathrm{C}$. The error jr. tlie nnasured dew pointe corresponds to an exror in the measured partial pressures of shaut $+10, \pm 5$ percent. Estimatec errorg in the measured flowgas pararieters are:

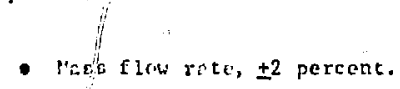


- Bacliground correction, \pm 2 percent of average gas-flow rate.

- Interpolation of dev poirt data during periods when gauge readouts vere not recorded, \pm 5 percent.

The estimeted total error in the water lost from the salt, which has been detertij:ed by this method, is $\pm \&$ percent.

\section{iest Results}

Table 2 sumarizes the results of the three water-loss analyses. A typical water-loss rate curve (i.e., the data for sample 2) is show in Iigurc 3. The characteristics of this water-loss tate curve that ore camon to all thres samples are:

- The monotonically declining late aftex the sample is placed in the enclosure at room temperature.

- Tue rate increase following an increase in the heater power with the actainrent of a maximum followed by a slow, monotonic decrease.

TARLE 2

Results for leated Salt Specimens

llass loss upor heating

Mine integral of net

vatci-loss rate

lass gain of desiccart

cortridges

\section{Lass Chonge $(g)$}

Salt Specinen Humber

$\begin{array}{rrr}-1 & \frac{2}{3} & \\ 1.26+0.06 & 0.98+0.06 & 1.47+0.06 \\ -0.03 & -0.03 & -0.03\end{array}$

$$
1.38 \pm 0.11 \quad 0.96 \pm 0.08 \quad 1.85 \pm 0.15
$$$$
1.14 \pm 0.05 \quad 0.98 \pm 0.05 \quad 1.32 \pm 0.05
$$

Average $\pm \mathrm{rms}$

$1.26 \pm 0.12$

$0.97 \pm 0.01$

$1.55 \pm 0.27$

lías g loes prodicted

fror heating curve for

20-e samplos and

scaled to specimen mass

$0.79 \pm 0.11$

$0.76 \pm 0.12$

$1.07 \pm 0.17$

llass loes in postheating pulse (200-nin interval), percent of total

$N / A$
0.097
0.112

9.0

5.5 


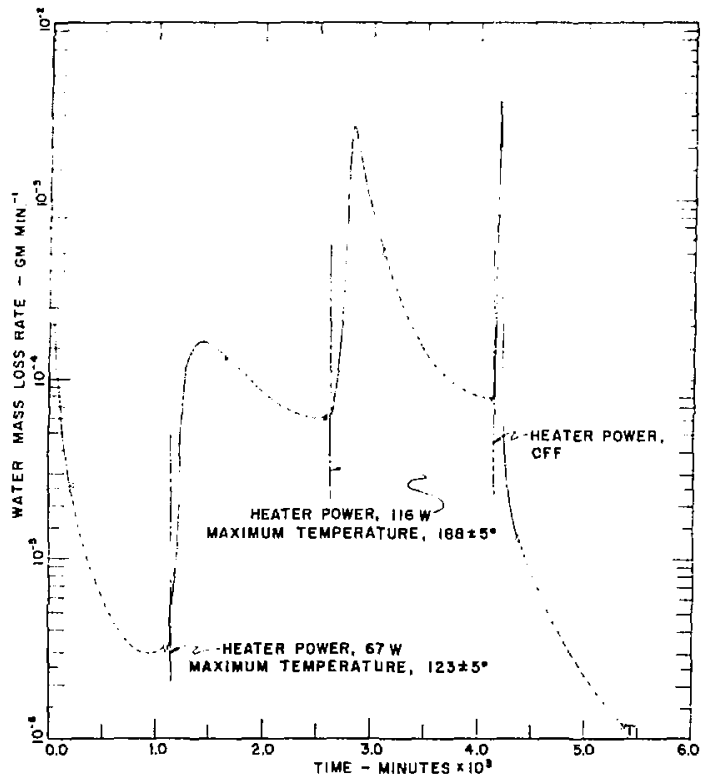

Firute 3. Representative Vater-Loss Rate of Heated Salt Specimen

The third specimen loet more water than the first two because it was raised to a higher maximun tomperature and because it dried for a ohorter cinc (only two weeks) prior to heating. Finally, two of the specinens showct an abrupt increase in water loss rate upon removal of heater power. (This may also have occurred during the first specimen's run, but the dew poirt gauge were not monitored after the power was turned of $f$.) The water roleased during this sudden outflow is 5 to 10 percent of the total unter released by the salt. The increase in the mas loss rate wilich occurs after the heater pover is changed is substantially higher during the postheating water loss "pulse" than it is following the two heater 
foter increases. For the second specimen, the relative maxima, along with the times of occurrence, are as follows:

$$
\text { Hater mass loss rates: } \begin{aligned}
& 1.6 \times 10^{-4} \mathrm{~g} \cdot \mathrm{min}^{-1} \text { at } 1445 \mathrm{~min} \\
& 2.6 \times 10^{-3} \mathrm{~g} \cdot \mathrm{min}^{-1} \text { at } 2825 \mathrm{~min} \\
& 5.24 \times 10^{-3} \mathrm{~g} \cdot \mathrm{min}^{-1} \text { at } 4185 \mathrm{~min}
\end{aligned}
$$

Vater mass loss Iate change rates: $2.1 \times 10^{-6} \mathrm{~g} \cdot \mathrm{min}^{-2}$ at $1225 \mathrm{~min}$

$6.7 \times 10^{-5} \mathrm{~g} \cdot \mathrm{min}^{-2}$ at $2788 \mathrm{~min}$

$3.2 \times 10^{-4} \mathrm{~g} \cdot \mathrm{min}^{-2}$ at $4180 \mathrm{~min}$

Table 2 includes the three values for each heated specimen's water lcss. In general, the values obtained by integrating the water-loss rate date are grcater than salt specimen mass losses, which, in turn, arc greater than desiccart cartridge mass gains. Water lost from heated, 1-kg salt specirens which have been measured three different ways are consistent to witlin an uverage of 9 percent. Additionaly, these data are in good agrement ( 30 percent) with mass loss meaurements of small samples $(20 \mathrm{~g})$ of similar raterial which were scaled to the specimen nucight. *

The rapid loss of water fron the salt specimens following the heater power turnof $f$ is similar to phenomena observed during measurements made in lieated geologic salt during project Salt Vault. ${ }^{2}$ A probable cause for the sudden release of weer fram the salt specimen following the power turnof is the openine of cracks or joints in the salt due to the tensile stress calsed by the cooling of the salt's surface naterial. Brine or water vapor contained within such a $\varepsilon$ teres sed region is released through material of an effectively and suddenly lasger permeability.

\footnotetext{
"A summa of these mearurements appears in Appendix 1.
} 
Taken together, the three methods of measuring the water lost from the heated geologic salt are adequate for detemining the water $106 \mathrm{~s}$ to within 10 percent. The use of desiccant cannisters to measure water is easy and inexpensive, but it yields values of water lost which average about 8 percent too low. Integrating the net water los 5 rate is complex, expensive, and subject to water sensor degradation, but it is the only way to rleasure time-dependent water loss. Measuring the mass lusi by the salt sample is convenient only if an appropriate balance is available. This rothod will not be practical for bench scale (several tons) salt samples.

i. Robert J. List, ed, Smithsonian Meteorological Tables, 6th rev, ed. (hashington, D. C.: Smithonian Institution, 1951), P. 350.

2. R. L. Bradshaw, et al, Project Salt Vault: A Demonstration of the Disposal of High-Activity Solidified Wastes in Underground Salt Mines, ORIL-4555 (0.1: Ridge, Tenn.: Oal: Ridge National Laboratory, 1971). 


\section{APPENDIX A}

MASS LOSS UPON IEATING OF GEOLOGIC SALT

\section{Int roduction}

This is a brief description of the mass loss measurements made on geclogic salt which arc referred to in the nain body of this report. He undertools these measurencnts in order to establish baseline data for mass losses upon heating of large specimens of geologic salt. Mass loss data were nceded in the design of other heated salt experiments. At one time we thought that the use of large samples (20 g) and, consequently, conventicnal analytical balances, as well as the capability of measuring scyeral samples at one time, appeared attrative.

Me thod

Wie took salt specinens from geologic salt similar to that used in the heated salt experiment described in this report. The experiment's simples cousisted of shards clipped, usjing a hammer and chisel, from a $0.3-\mathrm{m}$ long, cubic salt block. Each of the 10 samples contained from 3 to 16 pieces whose noss totaled nearly $20 \mathrm{~g}$. Each sample was placed in a covered glass vial and weighed at rom temperature. The vials were uncovered, and the samples vere placed in a desiccator containing desiccant and heated from one to 5 days at each of an ascending sequence of cemperatures from $: 5^{\circ}$ to $325 \mathrm{c}$. After heating the samples at the selected tamerature for several days, ve removed them from the oven, recovered them to prevent absorption cf moisture, cooled them to room temperature, and reweighed them. The specinens then were uncovered and reheated at the next higher temperature. Ir this fashion, meneurements of woight loss continued until one sample decrepitated. 
In generul, each sample decreased in mass after being heated at each of the elevated temperatures. Considerable sample variability was observed; "wct" samples consistently lost greater mass fractions at each temperature than "dry" samples. The results are sumarized in Figure A-1. The errors which are attached to each datum are the standard errors for tlie ten samples. Comparison with the results of Bonltinghouse and Sal lach* suggests that the mass 108 s curve which agrees with these data is tiost nearly that of type "A", characterized by diass los ses less than 0.5 percent.

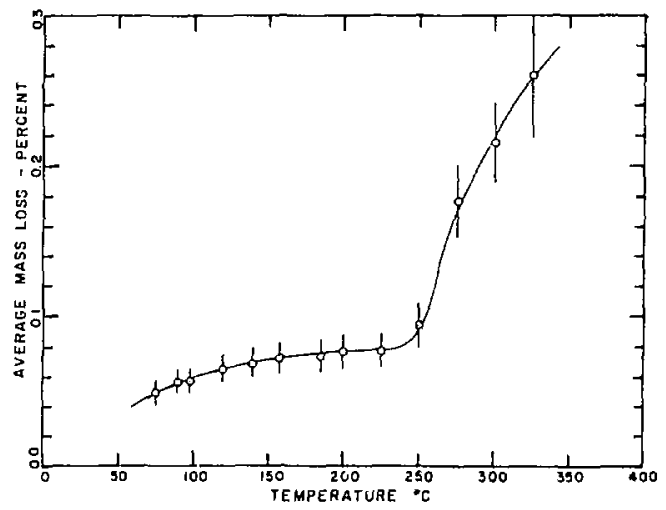

Figure $\Lambda^{-1}$. Mass Loss of Heared Salt, 20 Gram Samples

*k. D. Boultinghouse and R. A. Sallach, "Themogravimetric Analysis of ERIA f:g Core Somples," Memarandum to D. P. Powers, January 20, 1977. 
These samples displayed average mass losses of less than 0.1 percent after we heated them up to $250^{\circ} \mathrm{C}$. With the onset of decrepitation, an increase in the average mass loss to 0.26 percent was observed after leating the samples to $325^{\circ} \mathrm{C}$. 


\section{DISTRIBUTION :}

US Department of Energy, Headquarters (7) Olfice of Nuclear Waste Management Washington, DC 20545

At tn: E. F. Beckett Project Coordinatar (WIPP)
A. Heath, Director
R. Cooley
S. Meyers
R. Romatowski
K. Stein Division of waste Isalation

US Department of Energy (5)

Albuquerque Operations

P. 0. Box 5400

Albuquerque, NM 87185

Attn: D. T. Schueler, Manager (2) WIPP Project office

G. Densis, Director Public Affairs Division

5. C. Taylor CETI Division

R. Rudolph, Acting Deputy Mgr. WIPP Project office

US Department of Energy Cárlsbad WIPP Project office Room 113, Federal Building Carlsbad, NM 88220

US Department of Energy

c/o Battelle otfice of Nucleat waste Isolation

$505 \mathrm{King}$ Avenue

Col umbus, OH 43201

Actn: J, 0 . Nefe

Battelle Memorial Institute (5)

office of duclear Waste Isolation

505 King Avenue

Columbus, OH 43201

Attn: N. Carter, General Manager (3)

w. Garbiner

R. He ineman

Westinghouse Electric Corpat tion (4) P. O. Box 40039

Albuquerque, NM 87190

At 5 : R. C. Mairsou

D. Hulbert

A. K. Kuhn, D'Appolonia
Hobbs Public Library

$509 \mathrm{~N}$. Ship St.

Hobbs, NM 88248

Attn: Ms. M. Lewis, Librarian

New Mexico State University

Department of Civil Engineering

Box 3E

Las Cruces, NM 88003

At tn: L. Chaturvedi

Vanderbilt University

Department of Environmental and Water Resources Engineering

Nashville, IN 37235

Attn: F. L. Parker, Chairman

Stan ford University

Department of Geology

Stanford, CA 94305

Attn: K. B. Krauskopf, Vice Chairman

University of California

Dept. of Material Sciences and Eng.

Heart Mining Building, \#320

Berkeley, CA 94720

Attn: N, G. W. Cook

Inst. of Environmental Medicine New York University Medical Center Box 817

Tuxedo, NY 10987

Attn: M. Ei senbud

PPG Industrites, lnc.

Glass Research Center

Box 11472

Pitesburgh, PA 15238

Attn: F. M. Ernsberger

$\mathrm{Clark}$ University

Center for l'echnology, Environment and Davelopment

Worcester, MA 01610

At tn: R. Kasperson

Pennaylvania State University

Department of dydrogeology

University Park, PA 1680?

Attn: K. R. Parizck 
DISTRIBUTION: (cont)

University of California

Department of Nuclear Engineering

Berkeley, CA 94720

Attn: T. H. Pigford

University of Minnesota

lnstitute of Technology

Lind liall

Minneapolis, MN 55455

Attn: R. W. Staehle, Dean

Florida State University

Departinent of Oceanography

Tallahassee, FL 32306

Atta: J. W. Winchester

D'Arcy A. Shock, Consultant

233 Virginia

Ponca City, OK 74601

J. T. Holloway, Executive Secretary

2101 Constitution Avenue, NW

Hishington, DC 20418

WIPP Public Reading Room

At onic Museum

Kirtland East AFB

Albuquerque, NM 87185

Attn: G. Schreiner

WIPP Public Reading Room

Carlsbad Municipal Library

$101 \mathrm{~S}$. Hallagueno $\mathrm{St}$.

Carlsbad, NM 88220

AtLn: L. Hubbard, Head Librarian

Thomas Brannigan Library

$106 \mathrm{~W}$. Hadley $\mathrm{St}$.

Las Cruces, NM 88001

Attn: D. Dresp, Hezd Librarian

Koswell Public Library

301 N. Pennaylvania Avenue

Hoswel1, NM 88201

Attr: N. Langaton

Brown University

Department of Geological Sciences

Providence, RI 02912

Attn: 8. Giletti

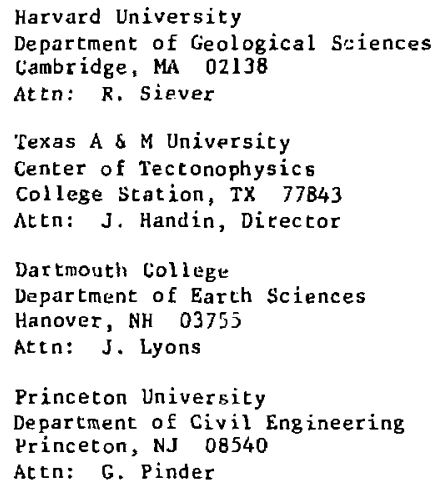

New Mexico Advisory Committee on WIPP (2) NMINI Graduate of fice

Socorro, NM 87801

Attn: M. H. Wilkening, Chairman

State of New Mexico (2)

Environmental Evaluation Group

3. S Marcy Street

P. 0. Box 968

Santa Fe, NM 87503

Attn: R. H. Neill, Nirector

NM Department of Energy \& Minerals (2)

P. 0. Box 2370

Senta Fe, NM 87501

Attn: 2 . Kehoe, Secretary

k. Laplante, Liberrian

Bechtel, Inc, (6)

P. 0. Box 3965

Son Francisco, CA 94119

Attn: J, Birkmyer

R. A, Langley

H. G. Teylor

P. K. Frobenius

D. L. Roberts

D. Duncan

Oak Kidge National Laboratory

Box $X$

Gak Ridge, TN 37830

Aten: G, H. Jenks 
DISTRLBUTION: (cont)

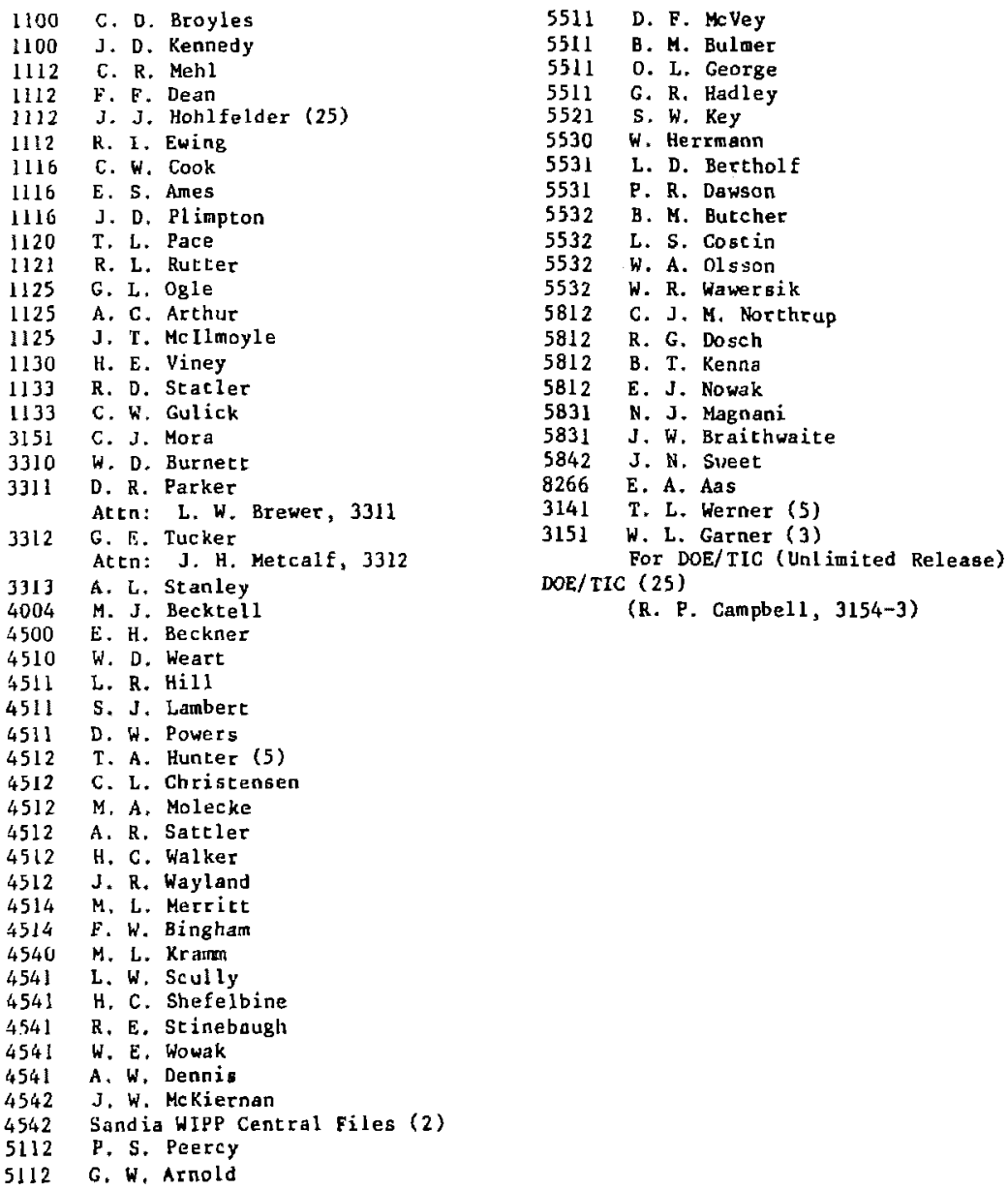

